\title{
Insights into Chufa Milk Frozen Yoghurt as Cheap Functional Frozen Yoghurt with High Nutritional Value
}

\author{
Seham Swelam ${ }^{1, *}$, Mohsen A. Zommara ${ }^{1}$, Abd El-Aziz M. Abd El-Aziz ${ }^{1}$, Noha A. Elgammal ${ }^{1}$, Roua S. Baty ${ }^{2}$ (I) \\ and Ehab Kotb Elmahallawy $3, *$ (D) \\ 1 Department of Dairy Science, Faculty of Agriculture, Kafrelsheikh University, Kafr El-Sheikh 33516, Egypt; \\ mzommara@agr.kfs.edu.eg (M.A.Z.); a_zizoa_abdo@yahoo.com (A.E.-A.M.A.E.-A.); \\ nohaelgammal2005@gmail.com (N.A.E.) \\ 2 Department of Biotechnology, College of Science, Taif University, P.O. Box 11099, Taif 21944, Saudi Arabia; \\ rsbaty@tu.edu.sa \\ 3 Department of Zoonoses, Faculty of Veterinary Medicine, Sohag University, Sohag 82524, Egypt \\ * Correspondence: seham.abdelhameed@agr.kfs.edu.eg (S.S.); eehaa@unileon.es (E.K.E.)
}

check for updates

Citation: Swelam, S.; Zommara, M.A.; Abd El-Aziz, A.E.-A.M.; Elgammal, N.A.; Baty, R.S.;

Elmahallawy, E.K. Insights into Chufa Milk Frozen Yoghurt as Cheap Functional Frozen Yoghurt with High Nutritional Value. Fermentation 2021, 7, 255. https://doi.org/10.3390/ fermentation7040255

Academic Editor: Senaka Ranadheera

Received: 11 September 2021

Accepted: 28 October 2021

Published: 2 November 2021

Publisher's Note: MDPI stays neutral with regard to jurisdictional claims in published maps and institutional affiliations.

Copyright: (c) 2021 by the authors. Licensee MDPI, Basel, Switzerland. This article is an open access article distributed under the terms and conditions of the Creative Commons Attribution (CC BY) license (https:/ / creativecommons.org/licenses/by/ $4.0 /)$.

\begin{abstract}
Milk and dairy products are fundamental items in all social groups' diets. The production of functional milk and dairy products supplemented with plant extracts is a potential direction of research in the dairy sector. In the present study, chufa (tiger nut) milk was mixed with buffalo milk for manufacturing functional frozen yoghurt. Flavoring materials (orange $(\mathrm{O})$, strawberry $(\mathrm{St})$, cocoa (Co), instant coffee "soluble coffee" classic (N) and cinnamon (Ci)) were used, aiming to improve the sensory attributes of the final products. The resultant frozen yoghurt was analyzed for chemical, physical and sensory properties. Interestingly, our study revealed that buffalo-chufa milk (50\%:50\%, w/w) frozen yoghurt (F) had higher total solid (TS), fat and protein contents compared to the control buffalo milk frozen yoghurt (CT). These parameters reached their highest values in cocoa frozen yoghurt (CoF). Lactose, acetaldehyde and $\mathrm{pH}$ were lower in $\mathrm{F}$ compared to $\mathrm{CT}$, while the highest acetaldehyde value was observed in strawberry chufa frozen yoghurt (StF). Plain or flavored F recorded higher petaldehyde values, observed in strawberry chufa frozen yoghurt (StF). Plain or flavored materials improved the melting resistance, and the highest value was recorded in cinnamon chufa frozen yoghurt (CiF). $\mathrm{Na}, \mathrm{K}, \mathrm{Mg}$, and Fe contents were significantly higher in F; however, $\mathrm{Ca}$ was lower compared to CT. In general, the used flavoring materials markedly increased the mineral content in the final products. A significant decrease was observed in the sensory properties in $\mathrm{F}$ compared to CT, whereas frozen yoghurt manufactured with coca was preferred over all other types, followed by the soluble coffee-flavored product (NF). Collectively, functional frozen yoghurt can be produced by mixing buffalo yoghurt and chufa milk (50:50 v/v). Buffalo—chufa frozen yoghurt (F) had higher nutritional value but lower physical and sensory properties compared to buffalo frozen yoghurt (control). A clear improvement in the properties of the final product can be achieved using different flavoring materials. Cleary, our present study provides novel interesting information about the potential beneficial use of chufa buffalo milk for manufacturing functional frozen yoghurt. Further similar research is recommended to explore the potential benefits of the supplementation of other dairy products with chufa.
\end{abstract}

Keywords: chufa milk; functional; frozen yoghurt; high nutritional value

\section{Introduction}

The use of food additives has been linked to an increase in health concerns. In this respect, recent research has focused on bioactive components and their usage in functional food production, combined with the rising demand in the area due to customer preferences for "natural," "organic," and "free of synthetic additives" food [1]. Functional foods are defined as foods that provide essential nutrition, while also having a favorable impact on the consumer's health [2-4]. Functional foods could include synthetic additive-free 
and nutritious natural foods that are ingested with the daily diet in food form, and which have a good impact on people's health; they also include bioactive food components, and diverse products supplemented with these components [5]. Plant additions contain vitamins, minerals, and other physiologically active compounds, which can boost the immune system. Furthermore, they enhance digestion and cardiovascular activity, and can also be used on a regular basis to restore the vital nutritional balance, in addition to being commercially feasible. Among others, chufa (tiger nut), "Cyperus esculentus L.", is an underutilized tuber that belongs to the family Cyperaceae and has many nutritional therapeutic advantages [6]. Its functional value comes from its high content of carbohydrate $(71.8 \%)$, which includes reducing sugar $(7.4 \%)$, soluble polysaccharide $(7.4 \%)$, starch $(31 \%)$ and fibers $(26 \%)$. It has a high level of fat (24.0-35.4\%, with about $70 \%$ oleic acid); protein (3.98-9.70\%, with a high level of essential amino acids), and vitamins (C and E) [7-12]. Reviewing the available literature, yellow chufa had a good amount of some essential minerals. In this regard, a previous study reported that raw tiger nuts had high contents of sodium (Na) and calcium (Ca), with mean values of $218.04 \mathrm{mg} / 100 \mathrm{~g}$ and $0.65 \mathrm{mg} / 100 \mathrm{~g}$, respectively [13]. However, the same study documented that processed tiger nuts had the following contents: $139.53 \mathrm{mg} / 100 \mathrm{~g}$ for $\mathrm{Na}$ and $0.00 \mathrm{mg} / 100 \mathrm{~g} \mathrm{Ca}$, which is lower than that of raw tiger nuts [13]. In stark contrast, this study reported high contents of some minerals in processed tiger nuts, such as $38,600.46 \mathrm{mg} / 100 \mathrm{~g}$ potassium $(\mathrm{K}), 10.9 \mathrm{mg} / 11 \mathrm{~g}$ iron $(\mathrm{Fe})$, $0.45 \mathrm{mg} / 100 \mathrm{~g}$ copper (CU), and $7.85 \mathrm{mg} / 100 \mathrm{~g}$ zinc (Zn) [13]. These contents and their mean values were significantly higher in comparison with those in raw tiger nuts, which had mean values of $1225.50 \mathrm{mg} / 100 \mathrm{~g}, 6.15 \mathrm{mg} / 100 \mathrm{~g}, 0.40 \mathrm{mg} / 100 \mathrm{~g}$ and $4.10 \mathrm{mg} / 100 \mathrm{~g}$ for $\mathrm{K}, \mathrm{Fe}, \mathrm{CU}$, and Zn, respectively [13]. Furthermore, another study [14] revealed that yellow chufa had higher $\mathrm{Na}$, Ca and $\mathrm{K}$ contents of $70.8 \mathrm{mg} / \mathrm{Kg}, 372.2 \mathrm{mg} / \mathrm{Kg}$, and $3694.43 \mathrm{mg} / \mathrm{Kg}$, respectively. Meanwhile, the same study revealed that yellow chufa had contents of $1.67 \mathrm{mg} / \mathrm{Kg}, 8.3 \mathrm{mg} / \mathrm{Kg}$ and $21.0 \mathrm{mg} / \mathrm{Kg} 0$ for $\mathrm{Mn}, \mathrm{Zn}$ and Fe, respectively [14]. On the other hand, small brown chufa had a higher $\mathrm{Mg}$ content of $308.3 \mathrm{mg} / \mathrm{Kg}$ [14]. However, it should be considered that these mean values were calculated on a dry weight basis. In a previous study, Zommara and Imaizumi (2017) [12] demonstrated that chufa tubers contain $12.38 \mu \mathrm{g} / \mathrm{g}$ and $8.46 \mu \mathrm{g} / \mathrm{g}$ of the isoflavones daidzein and genistein, respectively. Additionally, the same group reported that chufa oil contains about $18.6 \mathrm{mg} / 100 \mathrm{~g}$ oil of vitamin E and $168 \mathrm{mg} / 100 \mathrm{~g}$ oil of phytosterols [12,15]. Concerning its therapeutic value, chufa has the ability to prevent heart attacks and thrombosis, increase blood circulation, and prevent cancer risk, especially colon cancer [16]. It is suitable also for diabetic people, and helps in weight loss. In addition, it can be used to reduce cholesterol level due to its high contents of oleic acid and vitamin E $[12,15,17,18]$. Due to the previously mentioned benefits of chufa and its relatively low price, chufa has attracted a lot of interest as the basis of a nondairy milk, but there are some setbacks to using chufa milk as a beverage in Spain. "Horchata de chufa" is a very popular, refreshing drink consumed in Spain during the hot summer months. However, the high content of starch can give rise to undesirable sensory properties in chufa milk [19]. Using flavoring materials may be a way to improve its sensory attributes. In addition, using fruits as natural flavoring materials may improve the physical and nutritional properties of the final product.

Orange is a citrus fruit that is considered an excellent source of elements and vitamins required for the human body, such as vitamins C and B, potassium, and phosphorous [20]. Sidana et al. (2013) [21] revealed that orange fruits contain a wide range of bioactive compounds, such as phenolics and flavonoids, which play an important role in the prevention of several cardiovascular and chronic diseases, such as cancer and diabetes, besides their role in around $60-70 \%$ of liver diseases [22]. Strawberries are a common and important fruit owing to their high content of essential nutrients and beneficial phytochemicals that seem to have relevant biological effects on human health. Among these phytochemicals, anthocyanin and ellagitannins are the major antioxidant compounds [23]. Cinnamon contains very potent components, such as essential oils, resinous compounds, cinnamic acid, cinnamaldehyde and cinnamate. Cinnamon has pharmacological effects in the treatment of 
type II diabetes, and is regularly used to stave off the common cold and toothache, and aid digestion. In addition, the essential oil of cinnamon has an anti-microbial effect [24]. Cocoa powder is characterized by high contents of fat $(55.2 \%)$, protein $(21.6 \%)$ and ash $(3.5 \%)$. Furthermore, cocoa powder has mineral contents of 2313.1, 286.8, 236.6, 140.2, 3.4, 11.1 and $2.7(\mathrm{mg} / 100 \mathrm{~g})$ on a fresh weight basis for $\mathrm{K}, \mathrm{Mg}, \mathrm{P}, \mathrm{Ca}, \mathrm{Na}, \mathrm{Cu}$ and Fe, respectively [25]. Coffee is one of the most widely consumed beverages worldwide. Soluble coffee contains no significant amounts of macronutrients, fat, carbohydrates or proteins, and therefore, it is limited in its use as a flavoring material. The present study was undertaken to produce cheap functional frozen yoghurt with high nutritional value and health benefits using chufa milk. Natural fruits and some flavoring materials were also used to improve the physical and sensory properties of the resultant frozen yoghurt.

\section{Materials and Methods}

\subsection{Ethical Approval}

This study was conducted with the approval of the Faculty of Agriculture, Kafr Elshiekh University institutional Review Board Number KFS-Agri 2014/10.

\subsection{Materials}

Fresh buffalo milk was obtained from the farm of the Faculty of Agriculture at Kafrelsheikh University, Egypt. Chufa (yellow tiger nut) tubers (Cyperus esculentus) were obtained from a local market at Tanta city, Egypt, with the following composition: moisture $7.10 \%$, protein $6.20 \%$, fat $23.99 \%$, ash $1.81 \%$ and total carbohydrates $60.90 \%$. Yoghurt starter culture (YC-XII-DVS) consisting of Streptococcus thermophilus and Lactobacillus dellbreuckii subsp. bulgaricus at a ratio of 1:1 was obtained from CHR-Hansen's lab, Copenhagen, Denmark. Unicream120 is a commercial mixture of stabilizer and emulsifier that was obtained from the United Food Industries Co., Cairo, Egypt. Commercial granulated sugar was obtained from a local market at Kafr El-Sheikh, produced by Delta Sugar Company at Al-Hamoul, Kafr El-Sheikh, Egypt. Whey protein concentrate (WPC) 80\% was obtained from Nampa, ID, USA, with the composition of moisture $6.0 \%$, protein $80.0 \%$, fat $6.0 \%$, lactose $10 \%$ and minerals $4 \%$. Commercial sodium benzoate was obtained from Bio Jet Company, since it is considered as safe preservative at a daily intake of $<0.5 \mathrm{~g}$, according to the American Food and Drug Administration. Abu Auf ${ }^{\circledR}$ pure cocoa powder, orange, strawberry, cinnamon powder and classic soluble coffee were obtained from the local market at Kafr El-Sheikh city, Egypt.

\subsection{Manufacturing Methods}

\subsubsection{Preparation of Chufa Milk Base (CMB)}

Chufa milk was prepared according to the protocol described by Sanful (2009) [26]. A total of $900 \mathrm{~g}$ of chufa tubers were washed well then soaked overnight (12 h) to soften. The soaked chufa were then added to $2 \mathrm{~L}$ of distilled water and blended several times. The mash was then filtered through a muslin cloth to separate the milk from the mash. The final extract was mixed with 5\% WPC, 5\% sugar, $0.5 \%$ unicream and $0.1 \%$ sodium benzoate.

\subsubsection{Preparation of Juices}

Orange and strawberry were separately washed, then the edible part of the orange fruit was squeezed and strawberry was mixed in an electrical blender without adding water to get the juice. Orange juice was prepared by mixing the juice with 5\% WPC, 5\% sugar, $0.5 \%$ unicream and $0.1 \%$ sodium benzoate. The same ingredients were added to the strawberry juice.

\subsubsection{Preparation of Cinnamon Extract}

Hot aqueous extraction of $2 \%$ cinnamon powder was mixed with $5 \%$ WPC, $5 \%$ sugar, $0.5 \%$ unicream and $0.1 \%$ sodium benzoate. 


\subsubsection{Preparation of Frozen Yoghurt}

Plain yoghurt was prepared using the traditional method of Tamime and Robinson, (1999) [27]. Fresh buffalo milk (6\%) was inoculated with yoghurt starter culture and incubated at $42{ }^{\circ} \mathrm{C}$ until coagulation. The resultant yoghurt was used for preparing different blends $(n=3)$ of frozen yoghurt as follows:

(1) Control (CT) - plain yoghurt mixed with 5\% WPC, $5 \%$ sugar, $0.5 \%$ unicream and $0.1 \%$ sodium benzoate;

(2) Chufa frozen yoghurt (F) $-50 \%$ of $\mathrm{CT}$ mixed with $50 \% \mathrm{CMB}$;

(3) Orange-chufa frozen yoghurt $(\mathrm{OF})-50 \%$ of $\mathrm{CT}$ mixed with $50 \%$ of CMB-orange mixture $(50 \% \mathrm{CMB}+50 \%$ orange juice);

(4) Strawberry-chufa frozen yoghurt (SF) $-50 \%$ of CT mixed with $50 \%$ chufa milkstrawberry mixture $(65 \% \mathrm{CMB}+35 \%$ strawberry juice);

(5) Cocoa-chufa frozen yoghurt ( $\mathrm{CoF})-50 \%$ of $\mathrm{CT}$ mixed with $50 \%$ chufa milk-cocoa mixture $(\mathrm{CMB}+6 \%$ cocoa);

(6) Soluble coffee-chufa frozen yoghurt (NF) $-50 \%$ of CT mixed with $50 \%$ chufa milk soluble coffee mixture (CMB $+0.9 \%$ classic powder of soluble coffee);

(7) Cinnamon-chufa frozen yoghurt (CiF) $-50 \%$ of CT mixed with $50 \%$ chufa milkcinnamon mixture $(67 \% \mathrm{CMB}+33 \%$ cinnamons extract).

The used amount of every flavoring material was recommended after separate experiments in order to sensorially evaluate the most preferable percentage of each material from the consumers' point of view (data not shown). The sugar was adjusted in all treatments to $8 \%(w / w)$. The products were aged at $5 \pm 1{ }^{\circ} \mathrm{C}$ for $24 \mathrm{~h}$, then whipped in an ice creammaking machine (Mantematic 3, Cattabriga, Italy), packaged in suitable containers and stored at $-20^{\circ} \mathrm{C}$ until to be analyzed.

\subsubsection{Chemical Analysis of Frozen Yoghurt}

Total solids and protein were dried in an oven at $105^{\circ} \mathrm{C}$ for $3 \mathrm{~h}$ and measured using Kjeldahl's method. The ash content was determined as described by the Association of Official Agricultural Chemists (AOAC) (2007) [28], through drying all samples in an oven at $105{ }^{\circ} \mathrm{C} / 1 \mathrm{~h}$ followed by ignition in an electric muffle furnace at $550{ }^{\circ} \mathrm{C}$. Fat was determined according to the Soxhelt method through extraction of the fat from the sample using a solvent, then the weight of the fat recovered was determined as described by (AOAC, 2000) [29]. The minerals content (namely, iron $(\mathrm{Fe})$, potassium $(\mathrm{K})$, sodium $(\mathrm{Na})$, phosphorus $(\mathrm{P})$, magnesium $(\mathrm{Mg})$ and calcium $(\mathrm{Ca}))$ of the prepared beverages was determined by dissolving a fixed weight of ashed samples in a solution of hydrochloric acid ( $20 \mathrm{~N}$ or $2 \mathrm{~N})$, then their contents were determined using an Atomic Absorption Spectrophotometer (BB model Avanta $\Sigma$ mar GBC, Australia) according to AOAC (2000) [29]. Furthermore, Ling's (1963) [30] method was used for measuring acidity (\%) (as lactic acid) and the $\mathrm{pH}$ value was measured electrometrically using a Crison $\mathrm{pH}$ meter (Spain). Lactose was determined according to the method described by Barnett and Abd El-Twab (1957) [31] as follows: $0.25 \mathrm{~mL}$ of the sample was added to $250 \mathrm{~mL}$ of distilled water and 6 drops of phenol (80\%). Later, $5 \mathrm{~mL}$ sulfuric acid was added (with blowing) to $2 \mathrm{~mL}$ of the previously diluted solution, then elevated for about $10 \mathrm{~min}$ to room temperature. The concentration of the formed color was measured by a colorimeter at $490 \mathrm{~nm}$.

The method given by Finley and Fellers (1973) [32] was used for sucrose determination as follows: add $50 \mathrm{~mL}$ of $80 \%$ ethanol to $1 \mathrm{~g}$ of the sample and gently boil the mixture for $15 \mathrm{~min}$ followed by cooling to $20^{\circ} \mathrm{C}$ and dilution to $100 \mathrm{~mL}$ using $80 \%$ ethanol. Concurrently, run a reagent blank and a standard composed of $1 \mathrm{~mL}$ of $15 \% \mathrm{w} / \mathrm{v}$ sucrose solution $(15 \mathrm{~g}$ sucrose made up to $100 \mathrm{~mL}$ with water). The resulting mixture was then filtered through S\&S 576 filter paper followed by the addition of $1 \mathrm{~mL}$ of filtrate to $9 \mathrm{~mL}$ of Fehling solution in a test tube. Then heat in a boiling water bath for $15 \mathrm{~min}$ and cool to $20^{\circ} \mathrm{C}$. The rapid addition of $10 \mathrm{~mL}$ of anthrone reagent to $1 \mathrm{~mL}$ of this former solution was performed in a clean test tube, which was then held for $30 \mathrm{~min}$ at $40^{\circ} \mathrm{C}$. The absorbance was read at 
$610 \mathrm{~nm}$ against a reagent blank. The percentage of total apparent sucrose was calculated according the following equation:

$$
\text { Total apparent sucrose } \%=\text { sample } / \text { standard } \times 15 \text {. }
$$

Acetaldehyde content was measured according to the method described by Less and Jago (1969) [33]. In this method, acetaldehyde reacts with the semi carbazide solution that is pipetted on the inner well of the Conway microdiffusion cell, then $5 \mathrm{gm}$ of well-mixed sample is rapidly pipetted into the outer compartment and the cell is covered and placed in an incubator at $30^{\circ} \mathrm{C}$ for $90 \mathrm{~min}$. The solution in the inner well is transferred into a cuvette to measure absorbance at $224 \mathrm{~nm}$. The concentration of acetaldehyde was calculated from the standard curve of the acetaldehyde solution, ranging from 1 to $30 \mu \mathrm{mol} / 100 \mathrm{~mL}$.

\subsubsection{Physical Analysis}

The overrun was determined according to the method described by Marshall et al. (2003) [34] as a comparison of the weights of the yoghurt and frozen yoghurt, with an equal volume of each. The following formula was used for calculation:

$$
\begin{gathered}
\text { Overrun }[\%]=\text { weight of yoghurt }- \text { weight of frozen yoghurt } \times 100 \\
\qquad \text { Weight of frozen yoghurt }
\end{gathered}
$$

The melting rate of frozen yoghurt was measured according to the method of Rajascharan and Rajor (1988) [35]. For the measurement of the melting rate, after $24 \mathrm{~h}$ of hard freezing the frozen yoghurt samples $\left(-20^{\circ} \mathrm{C}\right)$, the samples with known weight $(10 \mathrm{~g})$ were placed on an iron mesh and held undisturbed for 15,30 and $45 \mathrm{~min}$ at $30 \pm 1{ }^{\circ} \mathrm{C}$. The weight of the melted frozen yoghurt as a percentage of the original weight was expressed as the melting rate. The apparent viscosity of the mixtures was evaluated after $24 \mathrm{~h}$ of aging. A digital Brookfield Viscometer (Model LVDV-E, Brookfield Engineering Laboratories, Inc., Cataumet, MA, USA) was used. Samples were tested in triplicate at $4{ }^{\circ} \mathrm{C}$ with spindle No. 64 at a speed of $50 \mathrm{rpm}$. The viscosity reading was recorded as centipoise (cp) [36].

\subsubsection{Sensory Evaluation}

This was performed following the suggested scoring card given by Nelson and Trout (1981) [37] by 20 professional panelists from the Faculty of Agriculture, Kafrelsheikh Univerisy. The following scoring points were used for different properties: taste (10 points), color (10 points), mouth feel (10 points) aroma (10 points) and overall acceptability (10 points).

\subsubsection{Statistical Analysis}

This was performed using the SPSS version (10) computer program (SPSS 2016) [38] Inc., Chicago, IL, USA. The results were subjected to ANOVA and Duncan's test to determine significant differences among means at the significance level of 0.05. Data are expressed as the means $\pm \mathrm{SE}$ of three replicates.

\section{Results and Discussion}

\section{Chemical Composition of Frozen Yoghurt}

Table 1 shows the gross chemical composition, acidity and $\mathrm{pH}$ value of frozen yoghurt as affected by adding chufa milk and different flavoring materials. Besides the $\mathrm{CiF}$ and OF, the total solid (TS) content was markedly increased compared to the control sample by adding all supplemented materials. Thus, the replacement of plain yoghurt with $50 \%$ of $\mathrm{CMB}$ for making frozen yoghurt increased the TS. At the same time, chufa-cocoa frozen yoghurt (CoF) achieved the highest content of TS (36.1\%). The protein content was found to be in the range of $4.62 \%$ to $7.30 \%$ (Table 1 ). The concentration of protein was increased remarkably in all treatments, except for OF, compared to the CT. It is interesting to note 
that the higher the protein content, the higher the fat content, since the OF sample had the lowest value (5.63\%), whereas CoF recorded the highest value $(9.65 \%)$. The ash content varied significantly in the tested samples, since CoF had the highest ash content (1.02\%). On the contrary, the OF recorded the lowest value $(0.75 \%)$. Similar changes in fat and acidity content due to using chufa with cow's milk $(3: 2 w / v)$ in yoghurt-making were given by Akoma (2000) [39]. In addition, El-Shenawy et al. (2012) [40] reported that TS content increased following the supplementation of yoghurt with $10 \%$ and $20 \%$ of chufa extract, while the protein and ash contents were decreased. Ezeonu et al. (2016) [41] demonstrated that chufa yoghurt had a higher content of fat, protein and carbohydrate compared to cow's yoghurt. Akubor (2016) [42] reported that yoghurt with 50\% orange juice had lower protein, fiber and ash contents compared to yoghurt without orange. The high gross chemical composition of $\mathrm{CoF}$ could be attributed to the high contents of fat, protein and ash of cocoa powder [25].

Table 1. Gross chemical composition, acidity and $\mathrm{pH}$ value of frozen yoghurt as affected by adding chufa milk and different flavoring materials.

\begin{tabular}{|c|c|c|c|c|c|c|c|c|c|c|}
\hline Products * & $\begin{array}{l}\text { TS } \\
(\%)\end{array}$ & $\begin{array}{l}\text { Fat } \\
(\%)\end{array}$ & $\begin{array}{l}\text { Protein } \\
\quad(\%)\end{array}$ & $\begin{array}{l}\text { Ash } \\
(\%)\end{array}$ & $\begin{array}{l}\text { Sucrose } \\
(\%)\end{array}$ & $\begin{array}{l}\text { Lactose } \\
\quad(\%)\end{array}$ & $\begin{array}{l}\text { Acetaldehyde } \\
\mu \mathrm{mol} / 100 \mathrm{~g}\end{array}$ & $\begin{array}{l}\text { Acidity } \\
\qquad(\%)\end{array}$ & $\begin{array}{c}\mathrm{pH} \\
\text { Value }\end{array}$ & $\begin{array}{c}\text { Lactose } \\
(\%)\end{array}$ \\
\hline CT & $\begin{array}{l}27.1 \pm \\
0.33^{c}\end{array}$ & $\begin{array}{l}5.88 \pm \\
0.07^{\mathrm{d}}\end{array}$ & $\begin{array}{l}4.62 \pm \\
0.05^{\mathrm{e}}\end{array}$ & $\begin{array}{l}0.85 \pm \\
0.01^{\mathrm{c}}\end{array}$ & $\begin{array}{c}8.27 \pm \\
0.18\end{array}$ & $\begin{array}{l}4.43 \pm \\
0.13^{a}\end{array}$ & $16.32 \underset{\mathrm{f}}{ \pm} 0.56$ & $\begin{array}{l}0.97 \pm \\
0.02\end{array}$ & $\begin{array}{l}4.69 \pm \\
0.01^{b}\end{array}$ & $\begin{array}{l}4.43 \pm \\
0.13^{a}\end{array}$ \\
\hline $\mathrm{F}$ & $\begin{array}{l}32.2 \pm \\
0.31^{\mathrm{b}}\end{array}$ & $\begin{array}{l}8.90 \pm \\
0.16^{\mathrm{b}}\end{array}$ & $\begin{array}{c}6.71 \pm \\
0.11^{\mathrm{b}}\end{array}$ & $\begin{array}{l}0.81 \pm \\
0.01 \mathrm{~cd}\end{array}$ & $\begin{array}{c}8.60 \pm \\
0.13\end{array}$ & $\begin{array}{l}3.70 \pm \\
0.03^{b}\end{array}$ & $24.06 \underset{\mathrm{d}}{ \pm} 0.35$ & $\begin{array}{l}1.02 \pm \\
0.03^{b}\end{array}$ & $\begin{array}{l}4.56 \pm \\
0.01^{\mathrm{c}}\end{array}$ & $\begin{array}{l}3.70 \pm \\
0.03^{b}\end{array}$ \\
\hline OF & $\begin{array}{l}24.8 \pm \\
0.31\end{array}$ & $\begin{array}{l}5.63 \pm \\
0.09 \mathrm{e}\end{array}$ & $\begin{array}{l}4.83 \pm \\
0.11^{\mathrm{e}}\end{array}$ & $\begin{array}{l}0.75 \pm \\
0.01 \mathrm{f}\end{array}$ & $\begin{array}{c}8.34 \pm \\
0.05\end{array}$ & $\begin{array}{l}2.52 \pm \\
0.03\end{array}$ & $27.85 \pm \underset{c}{ \pm} 0.30$ & $\begin{array}{l}1.17 \pm \\
0.05^{\mathrm{a}}\end{array}$ & $\begin{array}{l}4.38 \pm \\
0.01^{\mathrm{e}}\end{array}$ & $\begin{array}{l}2.52 \pm \\
0.03\end{array}$ \\
\hline SF & $\begin{array}{l}27.5 \pm \\
0.18^{c}\end{array}$ & $\begin{array}{l}7.87 \pm \\
0.01^{\mathrm{c}}\end{array}$ & $\begin{array}{l}5.38 \pm \\
0.63^{c}\end{array}$ & $\begin{array}{l}0.80 \pm \\
0.01 \mathrm{df}\end{array}$ & $\begin{array}{c}8.50 \pm \\
0.13\end{array}$ & $\begin{array}{l}2.87 \pm \\
0.03^{c}\end{array}$ & $\begin{array}{c}34.80 \pm 0.30 \\
\mathrm{a}\end{array}$ & $\begin{array}{c}0.96 \pm \\
0.04 \text { bcd }\end{array}$ & $\begin{array}{l}4.49 \pm \\
0.01^{\mathrm{d}}\end{array}$ & $\begin{array}{l}2.87 \pm \\
0.03^{c}\end{array}$ \\
\hline $\mathrm{CoF}$ & $\begin{array}{l}36.1 \pm \\
0.57^{\mathrm{a}}\end{array}$ & $\begin{array}{l}9.65 \pm \\
0.09^{\mathrm{a}}\end{array}$ & $\begin{array}{l}7.30 \pm \\
0.07^{\mathrm{a}}\end{array}$ & $\begin{array}{l}1.02 \pm \\
0.04^{\mathrm{a}}\end{array}$ & $\begin{array}{c}8.85 \pm \\
0.05\end{array}$ & $\begin{array}{l}3.67 \pm \\
0.01^{\mathrm{b}}\end{array}$ & $24.51 \underset{\mathrm{d}}{ \pm} 0.24$ & $\begin{array}{l}0.92 \pm \\
0.02 \mathrm{~cd}\end{array}$ & $\begin{array}{l}4.91 \pm \\
0.02^{\mathrm{a}}\end{array}$ & $\begin{array}{c}3.67 \pm \\
0.01\end{array}$ \\
\hline NF & $\begin{array}{c}32.5 \pm \\
0.22^{b}\end{array}$ & $\begin{array}{l}8.80 \pm \\
0.12^{b}\end{array}$ & $\begin{array}{l}6.87 \pm \\
0.07^{b}\end{array}$ & $\begin{array}{c}0.90 \pm \\
0.01^{\mathrm{b}}\end{array}$ & $\begin{array}{c}8.86 \pm \\
0.01\end{array}$ & $\begin{array}{c}3.61 \pm \\
0.08^{b}\end{array}$ & $32.11 \underset{b}{ \pm} 0.28$ & $\begin{array}{l}1.00 \pm \\
0.03^{b c}\end{array}$ & $\begin{array}{l}4.69 \pm \\
0.03^{b}\end{array}$ & $\begin{array}{l}3.61 \pm \\
0.08^{b}\end{array}$ \\
\hline $\mathrm{CiF}$ & $\begin{array}{l}25.6 \pm \\
0.49^{\mathrm{d}}\end{array}$ & $\begin{array}{l}6.22 \pm \\
0.07 \mathrm{~d}\end{array}$ & $\begin{array}{l}5.12 \pm \\
0.06^{\mathrm{d}}\end{array}$ & $\begin{array}{l}0.79 \pm \\
0.01 \mathrm{df}\end{array}$ & $\begin{array}{c}8.42 \pm \\
0.10\end{array}$ & $\begin{array}{c}2.79 \pm \\
0.08^{c}\end{array}$ & $\begin{array}{c}21.94 \pm 0.22 \\
\mathrm{e}\end{array}$ & $\begin{array}{c}0.86 \pm \\
0.02 \mathrm{e}\end{array}$ & $\begin{array}{l}4.52 \pm \\
0.02^{\mathrm{cd}}\end{array}$ & $\begin{array}{c}2.79 \pm \\
0.08^{c}\end{array}$ \\
\hline
\end{tabular}

* Refer to materials and methods for details. Data are expressed as Mean \pm SE. Different superscripts letters ( $a, b, c, d, e$ and f) indicate statistical significance between different treatmnets using chufa milk and the other flavoring materials. Means within the same column with different superscripts differ at $p \leq 0.05$.

Importantly, there were no significant differences in sucrose content among all examined frozen yoghurt samples, as it was adjusted to $8 \%$ in all products. The measured values ranged from 8.27 to 8.86 for control and NF, respectively (Table 1). As all the additives were free of lactose, its content was significantly reduced in all products compared to the control, while the lowest content was recorded for OF. Therefore, the products' contents of lactose could be attributed to their milk contents (Table 1). Considerable increases in acetaldehyde content were found in all products compared to the control (Table 1). Therefore, SF had the highest acetaldehyde value $(\mu \mathrm{mol} / 100 \mathrm{~g})(34.80)$ followed by NF (32.11), whereas the lowest content was recorded for the control sample, at 16.32 .

The acidity ranged between $0.86 \%$ and $1.17 \%$ for $\mathrm{CiF}$ and $\mathrm{OF}$. On the other hand, significant differences were noticed in the $\mathrm{pH}$ contents with all treatments, since the values of $\mathrm{pH}$ were between 4.38 and 4.91 for $\mathrm{OF}$ and $\mathrm{CoF}$, respectively. These results are in agreement with El-Shenawy et al. (2012) [40], who stated that the acetaldehyde content of yoghurt was increased markedly by adding tiger nut extract, and this increase was increased by increasing the tiger nut content. They added that the $\mathrm{pH}$ was reduced by using $10 \%$ of tiger nut extract, whereas the addition of $20 \%$ increased the $\mathrm{pH}$ significantly. Umelo et al. (2014) [43] reported that the acidity was higher in ice creams with 50\% tiger nut milk. This increase in the acetaldehyde and acid content of frozen yoghurt supplemented with tiger nut may be associated with the significant increase in starter culture, which stimulated the high nutritional properties (amino acid, vitamins and salts) of tiger nut extract $[44,45]$. Moreover, the decrease in lactose content was accompanied by a higher content acetaldehyde, which might be related to the lactose's metabolism into 
acetaldehyde during yoghurt fermentation, since almost $50 \%$ of the glucose consumed could be redirected towards acetaldehyde [46].

Figure 1 shows the changes in $\mathrm{pH}$ values of frozen yoghurt during 3 weeks of cold storage, as affected by using chufa milk flavored with different materials. At the beginning of the storage period, it is clear that using chufa with cocoa in the manufacturing of frozen yoghurt $(\mathrm{CoF})$ increased the $\mathrm{Pt}$ in the materials. At the beginning of storage, $\mathrm{CiF}$ had significantly lower $\mathrm{pH}$ values compared to the control sample, since SF recorded the lowest value (4.49). All $\mathrm{pH}$ values decreased gradually with the same trend throughout the storage period. Comparable changes in the $\mathrm{pH}$ during the storage of yoghurt were reported by Ozer et al. (2005) and Ramchandran and Shah $(2008)[47,48]$. The decrease in $\mathrm{pH}$ value during frozen storage might be attributed to the precipitation of calcium phosphate and the loss of disodium phosphate [49].

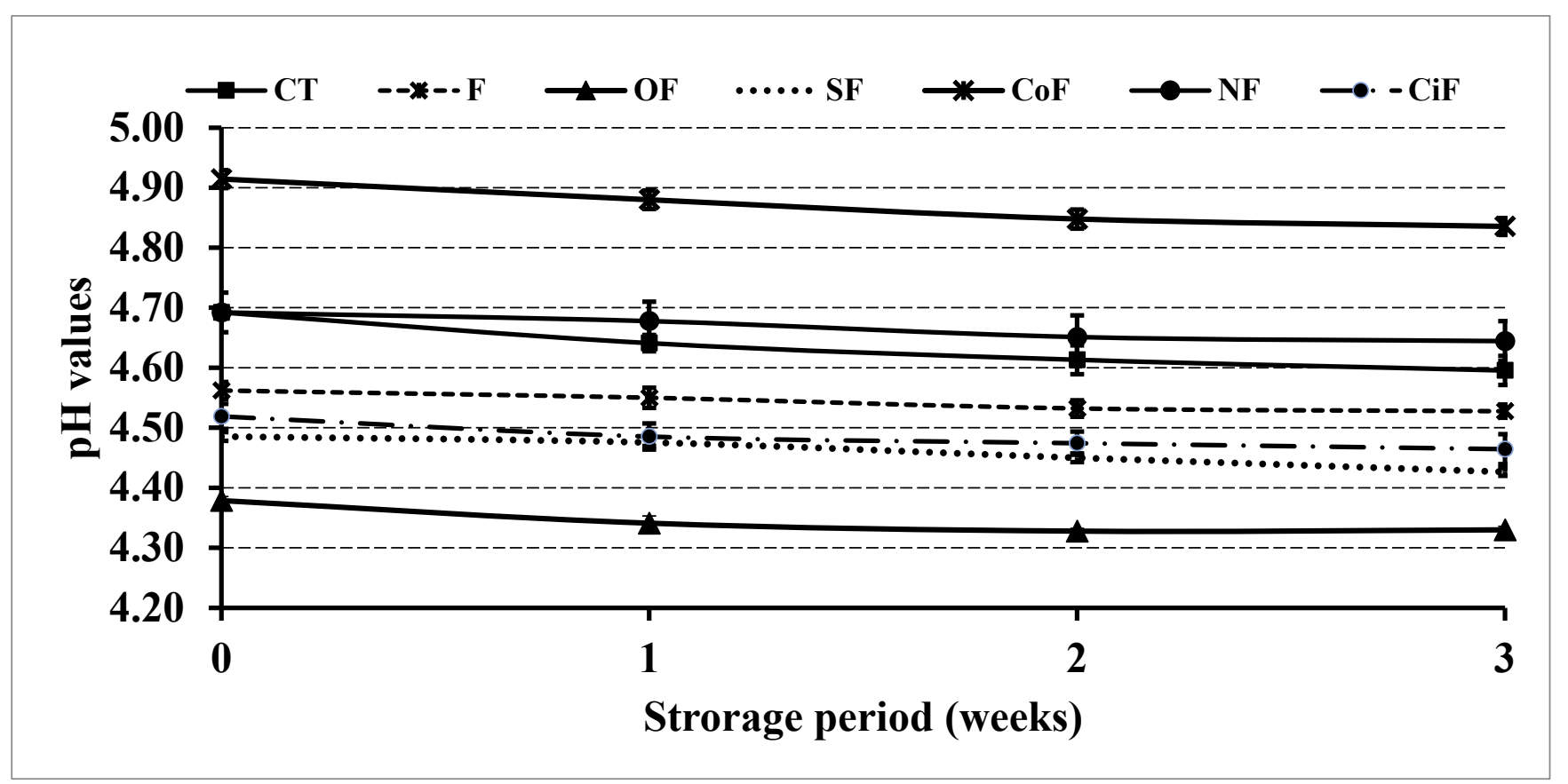

Figure 1. $\mathrm{pH}$ development of frozen yoghurt during storage as affected by using chufa milk and different flavoring materials (mean \pm SE of 3 replicates). Refer to materials and methods for treatments details.

The physical properties of frozen yoghurt are shown in Table 2. The physical properties of frozen yoghurt were improved considerably by the applied additives. Concerning the viscosity, it reached the highest value $(5466.7 \mathrm{Cp})$ in $\mathrm{CoF}$ frozen yoghurt, followed by $\mathrm{F}$ and $\mathrm{NF}$; however, the lowest value was recorded in the control sample (1647.78 Cp). Almost the same trend was detected in the overrun, since the highest value was recorded in $\mathrm{CoF}$ followed by NF, whereas F, OF and SF did not differ significantly, while the control sample had the lowest value. These results are in line with those of El-Shenawy et al. (2012) [40], who reported that using $10 \%$ chufa extract in the manufacture of yoghurt increased the viscosity significantly. The same results were reported for ice cream, since the viscosity of the mix was increased by increasing the percentage of chufa, while an insignificant impact was observed on the overrun [44]. On the other hand, Güven and Karaca 2002 [50] stated that strawberry can be used to increase the viscosity and overrun of frozen yoghurt. 
Table 2. Physical properties of frozen yoghurt as affected by using chufa milk and different flavoring materials (Mean $\pm \mathrm{SE}$ of 3 replicates).

\begin{tabular}{ccc}
\hline Treatments $^{*}$ & Viscosity (Cp) & Overrun (\%) \\
\hline CT & $1647.8 \pm 118.9^{\mathrm{e}}$ & $52.95 \pm 0.88^{\mathrm{e}}$ \\
F & $4597.2 \pm 89.2^{\mathrm{b}}$ & $67.79 \pm 1.70^{\mathrm{c}}$ \\
OF & $2351.1 \pm 64.5^{\mathrm{e}}$ & $68.41 \pm 1.01^{\mathrm{c}}$ \\
SF & $3414.4 \pm 98.5^{\mathrm{c}}$ & $68.71 \pm 0.95^{\mathrm{c}}$ \\
CoF & $5466.8 \pm 65.3^{\mathrm{a}}$ & $78.19 \pm 1.16^{\mathrm{a}}$ \\
NF & $4645.2 \pm 73.8^{\mathrm{b}}$ & $71.82 \pm 0.72^{\mathrm{b}}$ \\
CiF & $2981.1 \pm 59.1^{\mathrm{d}}$ & $64.28 \pm 0.75^{\mathrm{d}}$
\end{tabular}

* Refer to materials and methods for details. Data are expressed as Mean \pm SE. Different superscripts letters $(\mathrm{a}$, $\mathrm{b}, \mathrm{c}, \mathrm{d}$ and e) indicate statistical significance between different treatments using chufa milk and other flavoring materials. Means within the same column with different superscripts differ at $p \leq 0.05$.

Figure 2 shows the effects of the applied treatments on the melting resistance of the resultant frozen yoghurt. It is clear note that using chufa milk in the manufacture of frozen yoghurt increase the melting portion to $4.08 \%$ (F) after $10 \mathrm{~min}$ compared to $1.43 \%$ for the control sample. Moreover, insignificant differences were observed between control and CoF. On the other hand, the melting resistance was increased significantly by applying the other additives compared to the control, since the lowest melting portion was recorded by $\mathrm{CiF}$. The melting portion increased gradually with a consistent trend as a result of increasing the holding time, since after $50 \mathrm{~min}$ the highest melting portion was recorded in $\mathrm{F}(72.47 \%)$, while the lowest was found in $\mathrm{CiF}$ (26.69\%). In this regard, El-Shenawy et al. (2016) [40] reported that the melting rate was higher $(p>0.05)$ in ice cream made with different levels of tiger nut compared to the control one. Güven and Karaca (2002) [50] found that the melting resistance of frozen yoghurt decreased with the increase in strawberry concentration.

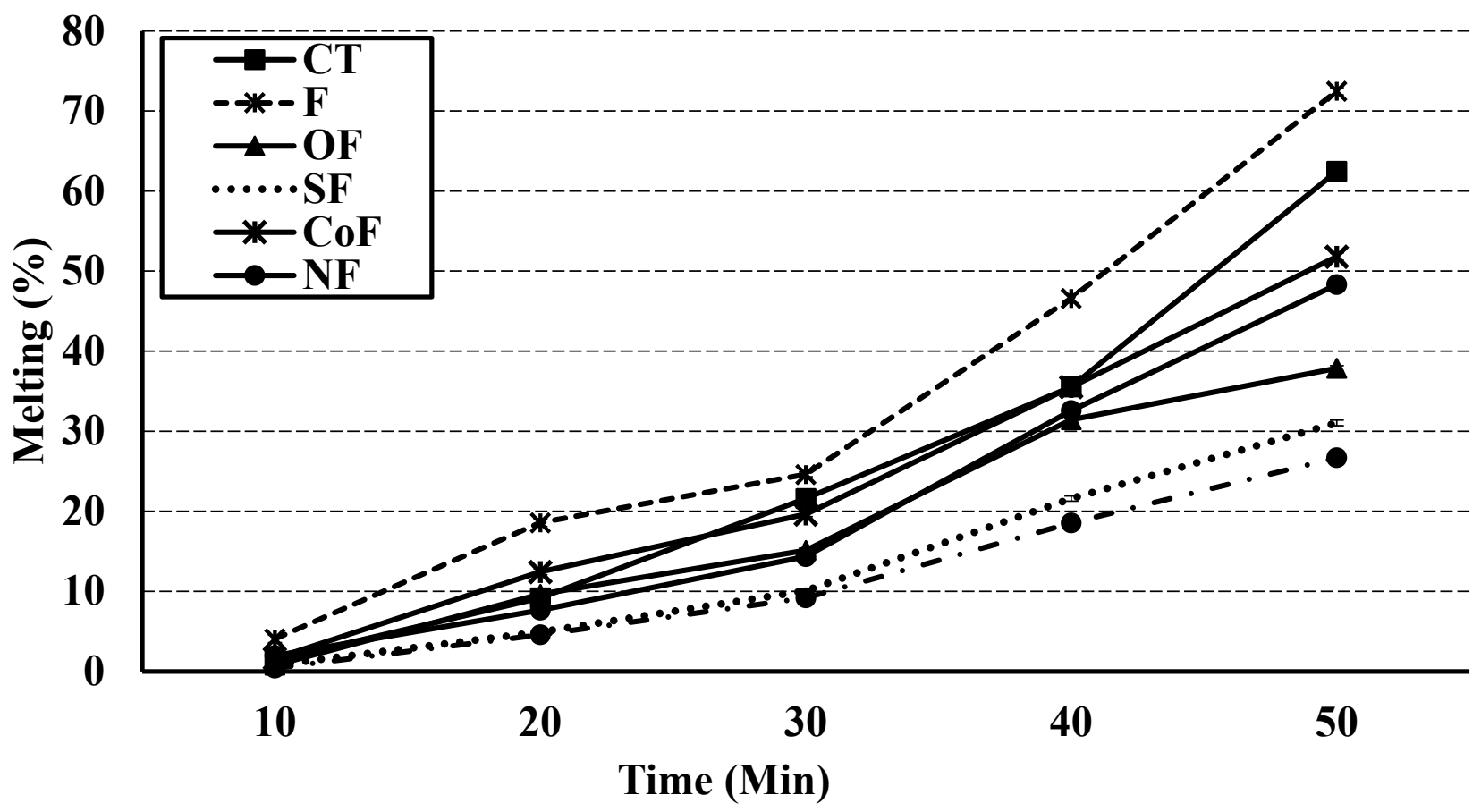

Figure 2. Melting rate of frozen yoghurt as affected by using chufa milk and different flavoring materials (Mean \pm SE of 3 replicates). Refer to Materials and Methods for treatment details.

The mineral contents of the produced frozen yoghurt are given in Table 3. All the measured minerals $(\mathrm{Na}, \mathrm{K}, \mathrm{Ca}, \mathrm{Mg}, \mathrm{P}$ and $\mathrm{Fe}$ ) varied significantly due to the applied additives. Adding $\mathrm{CMB}$ to buffalo milk (50 to 50\%) when making frozen yoghurt (F) 
led to increases in most of the measured minerals $(\mathrm{Na}, \mathrm{K}, \mathrm{Mg}$ and $\mathrm{Fe})$. On the other hand, the Ca content decreased significantly, while $\mathrm{P}$ did not differ, when using CMB. Moreover, the Ca content decreased in all treated samples-from $115.25 \mathrm{mg} / 100 \mathrm{~g}$ in the control to $75.00,77.90$ and $79.75 \mathrm{mg} / 100 \mathrm{~g}$ for OF, SF and CiF, respectively. There were insignificant differences among control, $\mathrm{F}$ and NF in terms of $\mathrm{P}$ content; furthermore, the highest content of $\mathrm{P}$ was detected in $\mathrm{CoF}(174.34 \mathrm{mg} / 100 \mathrm{~g})$, while CiF had the lowest content $(82.51 \mathrm{mg} / 100 \mathrm{~g})$. The data also reveal that the highest contents of $\mathrm{Na}$ and $\mathrm{Mg}$ were reported for F, CoF and NF, with insignificant differences between, whereas the lowest value was observed in $\mathrm{OF}$. On the other hand, $\mathrm{CoF}$ recorded the highest $\mathrm{K}$ content, followed by $\mathrm{F}$ and NF; however, $\mathrm{CiF}$ had the lowest value. The Fe content was more pronounced in all flavored treatments, since the control had the lowest content $(0.67 \mathrm{mg} / 100 \mathrm{~g})$, while it increased to $2.35 \mathrm{mg} / 100 \mathrm{~g}$ in CoF. Ezeonu et al. (2016) [41] reported that chufa yoghurt was lower in $\mathrm{K}, \mathrm{P}$ and $\mathrm{Ca}$ contents than cow's yoghurt. These differences in mineral content may be related to the high percentage of $\mathrm{Na}, \mathrm{K}, \mathrm{Mg}$ and $\mathrm{Fe}$ in chufa compared to buffalo milk, which contains high Ca and P contents [51]. Akubor (2016) [42] found an increase in the $\mathrm{K}$ content, but lower $\mathrm{Ca}$ and $\mathrm{F}$ levels, in yoghurt manufactured with $50 \%$ orange juice compared to the control (without any additives). On the other hand, cocoa frozen yoghurt ( $\mathrm{CoF}$ ) had the highest mineral content because of the high contents of $\mathrm{Na}, \mathrm{K}, \mathrm{Mg} \mathrm{P}$ and $\mathrm{Fe}$ in cocoa powder [25].

Table 3. Mineral contents ( $\mathrm{mg} / 100 \mathrm{~g}$ as a fresh weight) of frozen yoghurt as affected by using chufa milk and different flavoring materials.

\begin{tabular}{ccccccc}
\hline Treatments $^{*}$ & $\mathbf{N a}$ & $\mathbf{K}$ & $\mathbf{C a}$ & $\mathbf{M g}$ & $\mathbf{P}$ & Fe \\
\hline CT & $43.5 \pm 2.32^{\mathrm{b}}$ & $135.9 \pm 4.94^{\mathrm{e}}$ & $115.3 \pm 4.22^{\mathrm{a}}$ & $21.2 \pm 1.22^{\mathrm{d}}$ & $126.7 \pm 3.88^{\mathrm{b}}$ & $0.67 \pm 0.09^{\mathrm{e}}$ \\
F & $49.5 \pm 1.11^{\mathrm{a}}$ & $202.5 \pm 1.93^{\mathrm{b}}$ & $89.3 \pm 1.12^{\mathrm{b}}$ & $33.5 \pm 1.26^{\mathrm{a}}$ & $118.6^{\mathrm{a}} \pm 3.40^{\mathrm{b}}$ & $1.58 \pm 0.02^{\mathrm{b}}$ \\
OF & $29.9 \pm 1.30^{\mathrm{d}}$ & $181.9 \pm 2.00^{\mathrm{c}}$ & $75.0 \pm 1.90^{\mathrm{c}}$ & $28.8 \pm 1.30^{\mathrm{c}}$ & $68.4 \pm 4.50^{\mathrm{e}}$ & $0.80 \pm 0.00^{\mathrm{d}}$ \\
SF & $37.0 \pm 1.07^{\mathrm{c}}$ & $168.7 \pm 1.93^{\mathrm{d}}$ & $77.9 \pm 0.87^{\mathrm{c}}$ & $31.1 \pm 1.33^{\mathrm{abc}}$ & $94.1 \pm 0.86^{\mathrm{c}}$ & $0.91 \pm 0.01^{\mathrm{d}}$ \\
CoF & $49.6 \pm 0.43^{\mathrm{a}}$ & $332.5 \pm 1.09^{\mathrm{a}}$ & $93.9 \pm 1.18^{\mathrm{b}}$ & $35.1 \pm 0.88^{\mathrm{a}}$ & $174.3 \pm 1.06^{\mathrm{a}}$ & $2.35 \pm 0.08^{\mathrm{a}}$ \\
NF & $48.9 \pm 0.59^{\mathrm{a}}$ & $196.2 \pm 3.72^{\mathrm{b}}$ & $88.3 \pm 0.49^{\mathrm{b}}$ & $34.5 \pm 2.19^{\mathrm{a}}$ & $119.4 \pm 1.11^{\mathrm{b}}$ & $1.54 \pm 0.04^{\mathrm{b}}$ \\
CiF & $35.8 \pm 0.73^{\mathrm{c}}$ & $126.2 \pm 1.88^{\mathrm{f}}$ & $79.8 \pm 1.09^{\mathrm{c}}$ & $29.5 \pm 0.51^{\mathrm{bc}}$ & $82.5 \pm 2.54^{\mathrm{d}}$ & $1.13 \pm 0.01^{\mathrm{c}}$ \\
\hline
\end{tabular}

* Refer to Materials and Methods for details. Data are expressed as Mean \pm SE. Different superscripts letters ( $a, b, c, d, e$ and $f)$ indicate statistical significance between different treatments using chufa milk and other flavoring materials. Means within the same column with different superscripts differ at $p \leq 0.05$.

Table 4 shows the sensory evaluation of the produced frozen yoghurts. The sensory attributes were significantly different due to the applied flavoring materials. Generally, cocoa frozen yoghurt $(\mathrm{CoF})$ was the most acceptable for the panelists, whereas orange $(\mathrm{OF})$ and strawberry (SF) frozen yoghurt recorded the lowest total scores. However, as regards the flavor, CoF scored the highest value, followed by the control (CT) and NF samples without insignificant differences among them. In contrast, F, OF, SF and $\mathrm{CiF}$ had lower flavor values compared to the control. There were insignificant differences in body and texture between the control and the other treatments, whereas a significant improvement was observed for CoF and NF compared to F and SF. The highest (but insignificantly different) melting quality was detected in $\mathrm{CiF}$, whereas $\mathrm{F}$ had significantly lower melting quality compared to the control and other treatments. 
Table 4. Sensory evaluation of frozen yoghurt as affected by using chufa milk and different flavoring materials.

\begin{tabular}{cccccc}
\hline Treatments * $^{*}$ & $\begin{array}{c}\text { Flavour } \\
\mathbf{( 4 5 )}\end{array}$ & $\begin{array}{c}\text { Body and } \\
\text { Texture } \\
(\mathbf{3 0 )}\end{array}$ & $\begin{array}{c}\text { Melting } \\
\text { Quality } \\
\mathbf{( 1 5 )}\end{array}$ & $\begin{array}{c}\text { Colour and } \\
\text { Appearance } \\
(\mathbf{1 0 )}\end{array}$ & $\begin{array}{c}\text { Total } \\
\mathbf{( 1 0 0 )}\end{array}$ \\
\hline $\mathrm{CT}$ & $41.75 \pm 0.37^{\mathrm{a}}$ & $26.65 \pm 0.41^{\mathrm{ab}}$ & $12.35 \pm 0.35^{\mathrm{c}}$ & $8.90 \pm 0.18^{\mathrm{bc}}$ & $89.65 \pm 0.99^{\mathrm{b}}$ \\
$\mathrm{F}$ & $36.30 \pm 1.32^{\mathrm{c}}$ & $25.80 \pm 0.76^{\mathrm{b}}$ & $10.85 \pm 0.31^{\mathrm{d}}$ & $8.35 \pm 0.19^{\mathrm{c}}$ & $83.60 \pm 1.43^{\mathrm{c}}$ \\
$\mathrm{OF}$ & $38.45 \pm 1.37^{\mathrm{bc}}$ & $26.55 \pm 0.81^{\mathrm{ab}}$ & $13.35 \pm 0.28^{\mathrm{bc}}$ & $9.35 \pm 0.18^{\mathrm{ab}}$ & $87.20 \pm 2.14^{\mathrm{bc}}$ \\
$\mathrm{SF}$ & $36.75 \pm 1.12^{\mathrm{c}}$ & $25.95 \pm 0.59^{\mathrm{b}}$ & $13.9 \pm 0.19^{\mathrm{ab}}$ & $9.05 \pm 0.18^{\mathrm{ab}}$ & $83.75 \pm 1.59^{\mathrm{c}}$ \\
$\mathrm{CoF}$ & $43.55 \pm 0.42^{\mathrm{a}}$ & $28.10 \pm 0.45^{\mathrm{a}}$ & $13.00 \pm 0.33^{\mathrm{c}}$ & $9.55 \pm 0.13^{\mathrm{a}}$ & $95.20 \pm 0.87^{\mathrm{a}}$ \\
$\mathrm{NF}$ & $41.10 \pm 0.65^{\mathrm{ab}}$ & $27.85 \pm 0.36^{\mathrm{a}}$ & $12.8 \pm 0.38^{\mathrm{c}}$ & $9.1 \pm 0.20^{\mathrm{ab}}$ & $91.35 \pm 1.33^{\mathrm{ab}}$ \\
$\mathrm{CiF}$ & $38.55 \pm 0.63^{\mathrm{bc}}$ & $27.40 \pm 0.41^{\mathrm{ab}}$ & $14.5 \pm 0.11^{\mathrm{a}}$ & $8.9 \pm 0.26^{\mathrm{bc}}$ & $89.05 \pm 0.96^{\mathrm{b}}$ \\
\hline
\end{tabular}

* Refer to Materials and Methods for details. Data are expressed as Mean \pm SE for 3 replicates. Different superscripts letters ( $a, b, c$ and $d)$ indicate statistical significance between different treatments using chufa milk and other flavoring materials. Means within the same column with different superscripts differ at $p \leq 0.05$.

As shown in Figure S1, there was a degree of difference in the color and appearance of the flavored chufa beverages. CoF had the best color and appearance, while F showed the lowest score. These results are in agreement with those given by El-Shenawy et al. (2012) [40] and Ezeonu et al. (2016) [41], who found that the sensory attributes (appearance, body and texture and flavor) were significantly lower in yoghurt samples with chufa extract compared to the control (without chufa). Umelo et al. (2014) [43] added that the acceptability of ice cream decreased significantly with increases in its chufa milk content. On the other hand, Akoma (2000) [39] and Sanful (2009) [26] stated that an obvious enhancement was achieved by using a mixture of chufa and cow's milk in yoghurt manufacture. In addition, Bajwa et al. (2003) [52] stated that increasing the amount of strawberry used decreased the sensory evaluation of ice cream, whereas Palthur et al. (2014) [53] reported that the sensory evaluation was improved markedly by adding cinnamon powder to butter milk. However, the sensory scores of ice cream samples in terms of color, flavor, taste, mouth feel, and texture did not statistically differ when using cinnamon extract [54]. On the other hand, Akubor (2016) [42] reported that yoghurt made with $50 \%$ orange juice was preferred by the panelists over yoghurt alone.

\section{Conclusions}

Given the above information, functional frozen yoghurt can be produced by mixing buffalo and chufa milk (50:50 v/v). Buffalo-chufa frozen yoghurt (F) had higher nutritional values but lower physical and sensory properties compared to buffalo frozen yoghurt (control). A clear improvement in the properties of the final product can be achieved by using different flavoring materials. However, cocoa was the most recommended flavoring material for use in the production of buffalo-chufa frozen yoghurt, with the best nutritional, physical and sensory properties, followed by the soluble coffee-flavored product (NF). Further research is warranted to explore the bioavailability of some beneficial compounds present in chufa extract during yogurt production and storage.

Supplementary Materials: The following are available online at https:/ / www.mdpi.com/article/10 .3390/fermentation7040255/s1, Figure S1: the color and appearance of the flavored chufa beverage.

Author Contributions: S.S., M.A.Z., A.E.-A.M.A.E.-A. and N.A.E. were involved in the conception of the research idea and methodology design, supervision, data analysis and interpretation. R.S.B. and E.K.E. were involved in methodology, and drafting and preparing the manuscript for publication and revision. All authors have read and agreed to the published version of the manuscript.

Funding: This research received no external funding.

Institutional Review Board Statement: This study was conducted with the approval of the Faculty of Agriculture, Kafr Elshiekh University Institutional Review Board Number KFS-Agri 2014/10.

Informed Consent Statement: Not applicable. 
Data Availability Statement: The data that support the findings of this study are available on request from the corresponding author.

Acknowledgments: This work was supported by the Taif University Researchers Supporting Program (Project number: TURSP-2020/269), Taif University, Saudi Arabia.

Conflicts of Interest: The authors declare no conflict of interest.

\section{References}

1. Arslaner, A.; Salık, M. Functional bioactive components of milk. Erzincan Univ. J. Sci. Technol. 2019, 12, 124-135.

2. Hashemi, M.; Gheisari, H.R.; Shekarforoush, S. Preparation and evaluation of lowlshiekh University Institutional Review Board Number KFS-Agri 2014/10.ript. The Funders. Int. J. Dairy Technol. 2015, 68, 183-189. [CrossRef]

3. Mahmoudi, R.; Fakhri, O.; Farhoodi, A.; Kaboudari, A.; Rahimi Pir Mahalleh, S.; Tahapour, K.; Khayatti, M.; Chegini, R. A review on probiotic dairy products as functional foods reported from Iran. Int. J. Food Nutr. Saf. 2015, 6, 1-12.

4. Shahidi, F. Functional foods: Their role in health promotion and disease prevention. J. Food Sci. 2004, 69, R146-R149. [CrossRef]

5. Roberfroid, M.B. A European consensus of scientific concepts of functional foods. Nutrition 2000, 16, 689-691. [CrossRef]

6. Adel, A.; Awad, A.; Mohamed, H.; Iryna, S. Chemical composition, physicochemical properties and fatty acid profile of Tiger Nut (Cyperus esculentus L) seed oil as affected by different preparation methods. Int. Food Res. J. 2015, 22, 1931-1938.

7. Belewu, M.; Belewu, K. Comparative physico-chemical evaluation of tiger-nut, soybean and coconut milk sources. Int. J. Agric. Biol. 2007, 5, e787.

8. Bosch, L.; Alegria, A.; Farre, R. RP-HPLC determination of tiger nut and orgeat amino acid contents. Food Sci. Technol. Int. 2005, 11,33-40. [CrossRef]

9. Coşkuner, Y.; Ercan, R.; Karababa, E.; Nazlıcan, A.N. Physical and chemical properties of chufa (Cyperus esculentus L.) tubers grown in the Çukurova region of Turkey. J. Sci. Food Agric. 2002, 82, 625-631. [CrossRef]

10. Temple, V.J.; Ojobe, T.O.; Kapu, M.M. Chemical analysis of tiger nut (Cyperus esculentis). J. Sci. Food Agric. 1990, 50, 261-263. [CrossRef]

11. Zhang, H.Y.; Hanna, M.A.; Ali, Y.; Nan, L. Yellow nut-sedge (Cyperus esculentus L.) tuber oil as a fuel. Ind. Crop. Prod. 1996, 5, 177-181. [CrossRef]

12. Zommara, M.; Imaizumi, K. In Vitro antioxidant activity of chufa tubers (Cyperus esculentus L.) extracts in liposome peroxidation systems. J. Sustain. Agric. Sci. 2017, 43, 69-76. [CrossRef]

13. Madaki, F.M.; Kabiru, A.Y.; Muhammad, H.L.; Abubakar, A.N.; Bello, A. Comparative Nutritional Compositions of Raw and Processed Tiger Nuts (Cyperus esculentus L.). J. Intercult. Ethnopharmacol. 2015, 9, 32-40.

14. Imam, T.; Aliyu, F.; Umar Farouk, H. Preliminary Phytochemical Screening, Elemental and Proximate Composition of Two Varieties of Cyperus esculentus (Tiger Nut). Nig. J. Basic Appl. Sci. 2013, 21, 247-251. [CrossRef]

15. Zommara, M.A.; Imaizumi, K. Antiatherogenic effect of Tiger nut tubers (Cyperus esculentus L.) supplemented diet in apolipoprotein E knockout mice. J. Sustain. Agric. Sci. 2017, 43, 197-204. [CrossRef]

16. Adejuyitan, J.; Otunola, E.; Akande, E.; Bolarinwa, I.; Oladokun, F. Some physicochemical properties of flour obtained from fermentation of tigernut (Cyperus esculentus) sourced from a market in Ogbomoso, Nigeria. Afr. J. Food Sci. 2009, 3, 51-55.

17. Djomdi, D.; Kramer, J.; VanderJagt, D.; Ejoh, R.; Ndjouenkeu, R.; Glew, R. Influence of soaking on biochemical components of tiger nut (Cyperus esculentus) tubers cultivated in Cameroon. Int. J. Food Process. Eng. 2013, 1, 16-28.

18. Gambo, A.; Da'u, A. Tiger nut (Cyperus esculentus): Composition, products, uses and health benefits-a review. Bayero J. Pure Appl. Sci. 2014, 7, 56-61. [CrossRef]

19. Corrales, M.; de Souza, P.M.; Stahl, M.R.; Fernández, A. Effects of the decontamination of a fresh tiger nuts' milk beverage (horchata) with short wave ultraviolet treatments (UV-C) on quality attributes. Innov. Food Sci. Emerg. Technol. 2012, 13, 163-168. [CrossRef]

20. Abobatta, W.F. Nutritional benefits of citrus fruits. Am. J. Biomed. Sci. Res. 2019, 3, 303-306. [CrossRef]

21. Sidana, J.; Saini, V.; Dahiya, S.; Nain, P.; Bala, S. A review on Citrus-“"The boon of nature”. Int. J. Pharm. Sci. Rev. Res. 2013, 18, 20-27.

22. Fakayode, S.; Omotesho, O.; Babatunde, R.; Momoh, A. The sweet orange market in Nigeria, how viable? Res. J. Agric. Biol. Sci. 2010, 6, 395-400.

23. Giampieri, F.; Tulipani, S.; Alvarez-Suarez, J.M.; Quiles, J.L.; Mezzetti, B.; Battino, M. The strawberry: Composition, nutritional quality, and impact on human health. Nutrition 2012, 28, 9-19. [CrossRef]

24. Jakhetia, V.; Patel, R.; Khatri, P.; Pahuja, N.; Garg, S.; Pandey, A.; Sharma, S. Cinnamon: A pharmacological review. J. Adv. Sci. Res. 2010, 1, 19-23.

25. Afoakwa, E.O.; Quao, J.; Takrama, J.; Budu, A.S.; Saalia, F.K. Chemical composition and physical quality characteristics of Ghanaian cocoa beans as affected by pulp pre-conditioning and fermentation. J. Food Sci. Technol. 2013, 50, 1097-1105. [CrossRef] [PubMed]

26. Sanful, R.E. Production and sensory evaluation of tigernut beverages. Pak. J. Nutr. 2009, 8, 688-690. [CrossRef]

27. Tamime, A.Y.; Robinson, R.K. Yoghurt: Science and Technology; CRC Press: Boca Raton, FL, USA, 1999. 
28. AOAC. Official Method of Analysis, 18th ed.; Method 935.14 and 992.24.; Association of Officiating Analytical Chemists: Washington, DC, USA, 2005.

29. AOAC. Official Method of Analysis, 17th ed.; Methods 925.10, 65.17, 974.24, 992.16; The Association of Official Analytical Chemists: Gaithersburg, MD, USA, 2000.

30. Ling, E.R. Textbook of Dairy Chemistry; Springer: Berlin/Heidelberg, Germany, 1963.

31. Barnett, A.J.G.; Tawab, G.A. A rapid method for the determination of lactose in milk and cheese. J. Sci. Food Agric. 1957, 8 , 437-441. [CrossRef]

32. Finley, J.; DA, F. Sucrose determination by a modified anthrone method. application with sweetened wheat-soy blend and corn-soy-milk. Cereal Chem. 1973, 50, 210-215.

33. Lees, G.; Jago, G. Role of acetaldehyde in metabolism: A review 1. Enzymes catalyzing reactions involving acetaldehyde. J. Dairy Sci. 1978, 61, 1205-1215. [CrossRef]

34. Marshall, R.T.; Goff, H.D.; Hartel, R.W. Packaging, Labeling, Hardening and Shipping. In Ice Cream; Springer: Berlin/Heidelberg, Germany, 2003; pp. 225-252.

35. Rajasekaran, M.; Rajor, R. Manufacture of frozen yoghurt like product from soybean and skim milk/buttermilk solids. Indian J. Dairy Sci 1989, 42, 132-135.

36. Huse, P.; Towler, C.; Harper, W. Substitution of non-fat milk solids in ice cream with whey protein concentrate and hydrolyzed lactose. N. Z. J. Dairy Sci. Technol. 1984, 19, 255-261.

37. Nelson, J.A.; Trout, G.M. Judging of Dairy Products, 4th ed.; INC Westport; Academic Press: Cambridge, MA, USA, 1981; pp. 345-567.

38. Asthana, H.S.; Bhushan, B. Statistics for Social Sciences (with SPSS Applications); PHI Learning Pvt. Ltd.: New Delhi, India, 2016.

39. Akoma, O.; Elekwa, U.; Afodunrinbi, A.; Onyeukwu, G. Yogurt from coconut and tigernuts. J. Food Technol. Afr. 2000, 5, 132-134. [CrossRef]

40. El-Shenawy, M.; Abd El-Aziz, M.; El-Kholy, W.; Fouad, M. Probiotic yoghurt manufactured with tiger-nut extract (Cyperus esculentus) as a functional dairy food. J. Agric. Res. Nat. Resour. 2012, 1, $20-31$.

41. Ezeonu, C.S.; Tatah, V.S.; Nwokwu, C.D.; Jackson, S. Quantification of physicochemical components in yoghurts from coconut, tiger nut and fresh cow milk. Adv. Biotechnol. Microbiol. 2016, 1, 1-8.

42. Akubor, P. Effect of orange juice incorporation on the physicochemical, microbiological and sensory qualities of yoghurt. J. Food Nutr. Health 2016, 1, 1-7.

43. Umelo, M.; Uzoukwu, A.; Odimegwu, E.; Agunwah, I.; Njoku, N.; Alagbaoso, S. Proximate, physicochemical and sensory evaluation of ice cream from blends of cow milk and tigernut (Cyperus esculentus) milk. Int. J. Sci. Res. Innov. Technol. 2014, 1, 63-76.

44. El-Shenawy, M.; Abd El-Aziz, M.; Elkholy, W.; Fouad, M.T. Research Article Probiotic Ice Cream Made with Tiger-nut (Cyperus esculentus) Extract. Am. J. Food Technol. 2016, 11, 204-212. [CrossRef]

45. Mason, D. Tiger Nuts (Online); Retrieved on 5 December 2016; National Vegetable Society: UK, 2008.

46. Bongers, R.S.; Hoefnagel, M.H.; Kleerebezem, M. High-level acetaldehyde production in Lactococcus lactis by metabolic engineering. Appl. Environ. Microbiol. 2005, 71, 1109-1113. [CrossRef]

47. Akin, S.; Özer, D.; Özer, B. Effect of Inulin and Lactulose on Survival of "Lactobacillus Acidophilus" LA-5 and" Bifidobacterium Bifidum" BB-02 in Acidophilus-Bifidus Yoghurt. Food Sci. Technol. Int. Cienc. Tecnol. Aliment. Int. 2005, 11, 19-24.

48. Ramchandran, L.; Shah, N.P. Growth, proteolytic, and ACE-I activities of Lactobacillus delbrueckii ssp. bulgaricus and Streptococcus thermophilus and rheological properties of low-fat yogurt as influenced by the addition of Raftiline HP. J. Food Sci. 2008, 73, M368-M374.

49. Van den Berg, L.; Rose, D. Effect of freezing on the $\mathrm{pH}$ and composition of sodium and potassium phosphate solutions: The reciprocal system KH2PO4-Na2HPO4-H2O. Arch. Biochem. Biophys. 1959, 81, 319-329. [CrossRef]

50. Güven, M.; Karaca, O. The effects of varying sugar content and fruit concentration on the physical properties of vanilla and fruit fruit concentration on the physical properties of vanilla and fruit ice-cream-type frozen yogurts.s. Int. J. Dairy Technol. 2002, 55, 27-31. [CrossRef]

51. Ogunlade, I.; Bilikis, A.; Olanrewaju, A. Chemical compositions, antioxidant capacity of tigernut (Cyperus esculentus) and potential health benefits. Eur. Sci. J. 2015, 11, 217-224. Available online: https:/ / eujournal.org/index.php/esj/article/view/6532 (accessed on 30 October 2021).

52. Bajwa, U.A.; Huma, N.; Ehsan, B.; Jabbar, K.; Khurrama, A. Effect of different concentration of strawberry pulp on the properties of ice cream. Int. J. Agric. Biol. 2003, 15, 635-637.

53. Palthur, S.; Anuradha, C.; Devanna, N. Development and Evaluation of Cinnamon Flavored Buttermilk. Front. Food Nutr. Res. 2014, 1, 1-6.

54. Bikheet, M.M.; Abdel-Aleem, W.; Khalil, O. Supplemented Ice Milk with Natural Bioactive Components from Roselle Calyces and Cinnamon Extracts. J. Food Dairy Sci. 2018, 9, 229-235. [CrossRef] 